\title{
Inkompatibilitas Metode Omnibus Law Dalam Penyederhanaan Regulasi
}

\author{
Idul Rishan dan Imroatun Nika \\ Fakultas Hukum Universitas Islam Indonesia Yogyakarta Indonesia \\ Jln. Tamansiswa No. 158, Yogyakarta Indonesia \\ idul.rishan@uii.ac.id; imroatunnica@gmail.com
}

Received: 14 Juli 2021; Accepted: 16 November 2021; Published: 31 Januari 2022

DOI: 10.20885/iustum.vol29.iss1.art8

\begin{abstract}
This study focuses on the application of the omnibus law method in the simplification of regulations. This study aims to analyze two things. First, the application of the omnibus law method in the simplification of regulations in Indonesia. Second, formulating the reasons from which the omnibus method is not compatible in the simplification of regulations. The method used is a doctrinal legal research based on secondary data. The results of the study conclude that: (1) there are 11 regulatory clusters in the Job Creation Law with 81 affected laws and 2 repealed laws. By the time this study was completed, the omnibus law method had produced 47 Government Regulations and 4 Presidential Regulations. (2) there is no correlation between the usefulness of the omnibus law method and the efforts to simplify regulations. There are three reasons behind it, which includes: (a) the absence of regulatory normality threshold indicators (b) the omnibus method is more compatible to be used as a technique for simplifying regulations and (c) the omnibus law method creates the need for complex regulatory synchronization and has the potential to increase the volume of regulation.
\end{abstract}

Key Words: Omnibus law; simplification of regulations; job creation

\section{Abstrak}

Studi ini difokuskan pada penerapan metode omnibus law dalam penyederhanaan regulasi. Penelitian ini bertujuan untuk menganalisis dua hal. Pertama, penerapan metode omnibus law dalam penyederhanaan regulasi di Indonesia. Kedua, merumuskan alasan bahwa metode omnibus tidak kompatibel dalam menyederhanakan regulasi. Metode penelitian ini merupakan penelitian hukum doktriner dengan basis data sekunder. Hasil penelitian menyimpulkan: (1) terdapat 11 klaster pengaturan dalam UU CK dengan 81 undang-undang terdampak dan 2 undang-undang yang dicabut. Sampai dengan studi ini diselesaikan, metode omnibus law telah melahirkan 47 PP dan 4 Perpres. (2) tidak ada korelasi antara kegunaan metode omnibus dengan upaya penyederhanaan regulasi. Tiga alasan yang melatarbelakangi antara lain: (a) ketiadaan indikator ambang batas kenormalan regulasi (b) metode omnibus lebih kompatibel digunakan sebagai teknik penyederhanaan legislasi dan (c) metode omnibus law melahirkan kebutuhan sinkronisasi regulasi yang kompleks dan potensial menambah volume regulasi.

Kata-kata Kunci: Omnibus law; penyederhanaan regulasi; cipta kerja 


\section{Pendahuluan}

Banyak studi dalam lanskap keilmuan yang menguatkan sebuah preposisi bahwa metode omnibus merupakan bagian integral dalam upaya menyederhanakan regulasi dari segi jumlah. Preposisi ini dibangun atas kecenderungan besarnya kuantitas regulasi di tingkat pusat dan daerah yang memicu berbagai macam ekses dalam sistem perundang-undangan. Studi Antoni Putra pada di trimester awal 2020, mencatatkan bahwa salah satu faktor pendorong besar yang menginisiasi lahirnya metode omnibus berangkat dari pembengkakan jumlah regulasi yang berdampak pada lemahnya pertumbuhan ekonomi dan investasi. ${ }^{1}$

Studi Putra berangkat dari hasil penelitian sebelumnya yang ditegakkan Pusat Studi Hukum dan Kebijakan yang menyatakan bahwa jumlah regulasi yang dihasilkan di Tingkat Pusat (Periode 2014-Oktober 2018) telah mengalami hiperregulasi pada empat sektor yaitu Undang-Undang, Peraturan Pemerintah, Peraturan Presiden dan Peraturan Menteri.

Tabel 1: Kuantitas Regulasi Periode 2014-Oktober $2018^{2}$

\begin{tabular}{lcl}
\hline \multicolumn{1}{c}{ Jenis Peraturan } & Jumlah & \multicolumn{1}{c}{ Implikasi Potensial } \\
\hline Undang-Undang & 107 & Beban Tumpang Tindih \\
Peraturan Pemerintah & 452 & Beban Harmonisasi \\
\hline Peraturan Presiden & 765 & Beban Sinkronisasi \\
\hline Peraturan Menteri & 7621 & Beban Monitoring dan Evaluasi \\
\hline
\end{tabular}

Tidak berbeda jauh dari studi Putra, masih di awal trimester 2020, Bayu Anggono, Wacipto Setiadi dan Mayasari ${ }^{3}$ menguatkan penelitian sebelumnya dengan menyatakan bahwa omnibus merupakan alternatif metode untuk menyederhanakan atau melakukan simplifikasi regulasi. Meskipun pada beberapa anasir tertentu, hasil studi Anggono sebenarnya tidak menyatakan

1 Presiden Joko Widodo (Jokowi) mengatakan bahwa regulasi yang banyak menghambat ekonomi dan investasi. Kewajiban seperti Izin Lingkungan, Analisis dampak lingkungan (Amdal) dan kewajiban Izin Mendirikan bangunan (IMB) menyulitkan investor. Oleh sebab itu, regulasi yang banyak harus dikurangi, serta kewajiban Amdal dan IMB dalam perizinan investasi harus dihapuskan. Oleh karenanya Omnibus law diadopsi sebagai pilihan politik hukum yang menitikberatkan pada penyederhanaan jumlah regulasi karena sifatnya yang merevisi dan mencabut banyak undang-undang sekaligus. Lihat Antoni Putra, Penerapan Omnibus law Dalam Upaya Reformasi Regulasi, “Jurnal Legislasi Indonesia, Vol. 17 No. 1 - Maret 2020, hlm. 2.

2 Lihat Pusat Studi Hukum dan Kebijakan Indonesia, Kajian Reformasi Regulasi di Indonesia: Pokok. Permasalaban dan Strategi Penanganannya, PSHK, Jakarta, 2019, hlm. 65:

3 Lihat Ima Mayasari, "Kebijakan Reformasi Regulasi Melalui Implementasi Omnibus Law", Jurnal Rechtsvinding Volume 9 Nomor 1, April 2020, hlm. 14. 
bahwa metode ini mampu menyederhanakan beban regulasi. Hanya saja studi Anggono tidak menafikkan bahwa ide yang melatarbelakangi metode ini tidak dapat dipisahkan dari keinginan pemerintah untuk merampingkan struktur regulasi di tingkat pusat maupun daerah. ${ }^{4}$

Sementara pada penelitian Setiadi menegaskan bahwa metode omnibus menjadi sebuah keniscayaan untuk melakukan simplifikasi regulasi yang dinilai telah mengalami "obesitas". Setiadi membangun analisanya dengan berkaca pada data Kementerian Hukum dan HAM di awal Januari 2020.

Tabel 2: Jumlah Regulasi /tanggal 16 Januari 20205

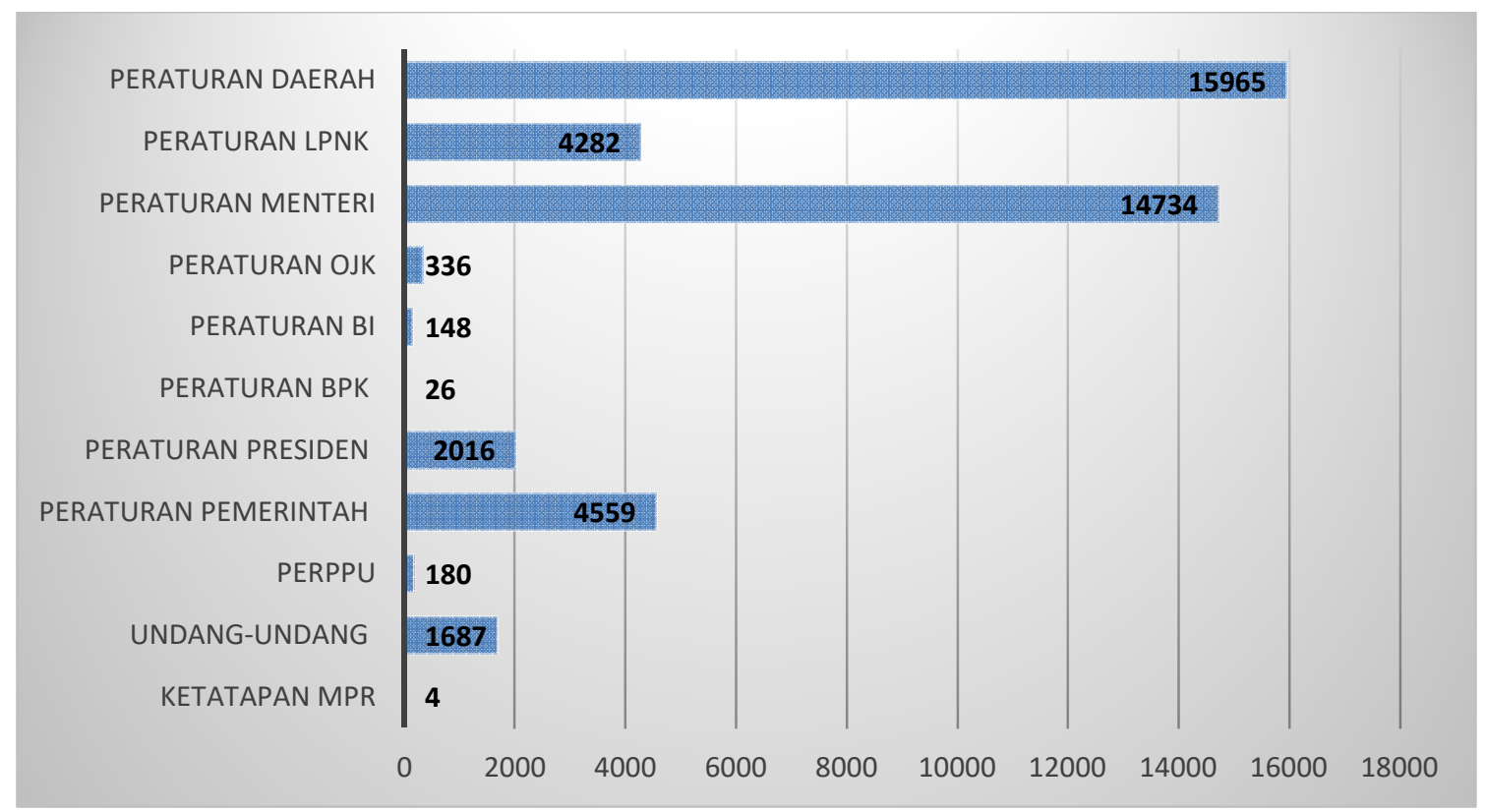

Pendekatan omnibus oleh karenanya merupakan terobosan baru untuk menekan terjadinya hiper-regulasi. ${ }^{6}$ Beberapa data di atas juga semakin dikuatkan dengan naskah akademik RUU Cipta Kerja yang salah satu tujuannya ialah melakukan penyederhanaan regulasi. ${ }^{7}$ Dari beragam pendekatan, data, dan

\footnotetext{
${ }_{4}^{4}$ Tujuan dibuatnya metode omnibus law menurut Presiden adalah untuk mengatasi segala bentuk kendala regulasi yang tengah dialami Indonesia, sehingga regulasi perlu disederhanakan, dipotong dan dipangkas jumlahnya. Lihat Bayu Dwi Anggono, "Omnibus Law Sebagai Teknik Pembentukan Undang-Undang: Peluang Adopsi dan Tantangannya Dalam Sistem Perundang-Undangan Indonesia”, Jurnal Rechtsvinding Volume 9 Nomor 1, April 2020, hlm 18

5 Wacipto Setiadi, “Simplifikasi Regulasi Dengan Menggunakan Metode Pendekatan Omnibus Law”, Jurnal RechtsVinding, Vol. 9 No. 1, April 2020, hlm. 40

${ }^{6}$ Ibid., hlm. 45.

${ }^{7}$ Kehadiran RUU Cipta Kerja dalam rangka melakukan reformasi regulasi. Dalam konteks administrative regulation, reformasi diarahkan ke perampingan/penyederhanaan dan peningkatan efisiensi regulasi. Lihat Naskah Akademik, Rancangan Undang-Undang Cipta Kerja, Sekretariat DPR RI, Jakarta, 2019, hlm. 49
} 
analisis yang ditawarkan, pada prinsipnya penulis mengakui bahwa hasil studi terdahulu telah memperkaya pengetahuan di bidang keilmuan maupun praktis. Tanpa menafikan keragaman hasil studi yang telah ada, penulis berada dalam pandangan dan pendekatan yang berbeda. Setidaknya dalam melihat kompatibilitas metode omnibus dalam upaya penyederhanaan regulasi. Studi ini akan mencoba merespons penelitian terdahulu, dengan membuktikan bahwa metode omnibus tidak serta merta menjadi jawaban atas upaya penyederhanaan regulasi.

\section{Rumusan Masalah}

Berdasarkan latar belakang permasalahan yang dirumuskan oleh penulis, penelitian ini menawarkan dua rumusan masalah yang akan di jawab secara deskriptif analitis. Masing-masing rumusan masalah sebagai berikut: pertama, bagaimana penerapan metode omnibus dalam pembentukan regulasi di Indonesia? Kedua, mengapa metode omnibus tidak kompatibel dalam upaya penyederhanaan regulasi?

\section{Tujuan Penelitian}

Sebagaimana telah diuraikan dalam rumusan masalah, penelitian ini bertujuan untuk memperoleh dua hal. Pertama, untuk menganalisis penerapan metode omnibus dalam pembentukan regulasi di Indonesia. Kedua, untuk merumuskan alasan yang melegitimasi bahwa metode omnibus tidak kompatibel dalam menyederhanakan regulasi.

\section{Metode Penelitian}

Penelitian ini merupakan penelitian hukum doktriner dengan menggunakan pendekatan perundang-undangan dan konseptual. Jenis data yang digunakan adalah data sekunder dan disajikan secara deskriptif kualitatif. Studi difokuskan pada Undang-Undang Nomor 11 Tahun 2020 tentang Cipta Kerja (UUCK) sebagai produk omnibus pertama hasil kinerja legislasi antara Presiden dan DPR. Objek kajian dibatasi pada klaster administrasi pemerintahan, yang berdampak pada UU Pemerintahan Daerah, UU Administrasi Pemerintahan dan UU Desa. 
Pembatasan objek kajian pada klaster administrasi pemerintahan untuk memperkuat validitas dan realibilitas data dalam penulisan studi ini. ${ }^{8}$

\section{Hasil Penelitian dan Pembahasan}

\section{Penerapan Metode Omnibus Law di Indonesia}

Sebagai sebuah metode yang terbilang baru di Indonesia, omnibus telah menjadi pilihan politik hukum pemerintah guna melakukan pembentukan dan perubahan di berbagai sektor regulasi yang meliputi investasi dan kemudahan berusaha ke dalam satu undang-undang. Berdasarkan hasil identifikasi terhadap pengundangan UU Cipta Kerja, penulis memetakan terdapat beberapa UU terdampak, UU yang dicabut, pengelompokan berdasarkan klaster, serta pengaturannya ke dalam bentuk PP dan Perpres.

Tabel 1: Struktur Omnibus law Cipta Kerja

\begin{tabular}{lll}
\hline No & UU No 11 Tahun 2020 tentang Cipta Kerja & \multicolumn{1}{c}{ Jumlah } \\
\hline 1 & UU Terdampak & 81 Undang-Undang \\
2 & UU yang Dicabut & 2 Undang-Undang \\
\hline 3 & Klaster Pengaturan & 11 Klaster $^{10}$ \\
\hline 4 & Pengaturan Ke PP & 47 PP11 $^{11}$ \\
\hline 5 & Pengaturan Ke Perpres & 4 Perpres $^{12}$ \\
\hline
\end{tabular}

${ }^{8}$ Selain itu, pilihan atas batasan objek yang diteliti dipengaruhi oleh alasan objektif dan subjektif. Secara objektif klaster administrasi pemerintahan telah berdampak pada perubahan tiga undang-undang sekaligus yaitu UU Pemerintahan Daerah, UU Administrasi Pemerintahan dan UU Desa. Sementara alasan subjektifnya, batasan ini semata-mata dilakukan untuk menyesuaikan jangka waktu penelitian dan besaran dana yang disediakan.

${ }_{9}^{9}$ UU No 3 Tahun 1982 Tentang Wajib Daftar Perusahaan dan Staatsblad Tahun 1926 Nomor 226 juncto Staatsblad Tahun 1940 Nomor 450 tentang Undang-Undang Gangguan (Hinderordonnantie)

1011 klaster, yaitu: 1) Penyederhanaan Perizinan, 2) Persyaratan Investasi, 3) Ketenagakerjaan, 4) Kemudahan, Pemberdayaan, dan Perlindungan UMK-M, 5) Kemudahan Berusaha, 6) Dukungan Penelitian dan Inovasi, 7) Administrasi Pemerintahan, 8) Pengenaan Sanksi, 9) Pengadaan Lahan, 10) Investasi dan Proyek Pemerintah, dan 11) Kawasan Ekonomi.

${ }_{11}$ Dari 47 PP yang dibentuk pasca omnibus law, hanya terdapat 4 PP yang mengubah PP yang lama yaitu; (1) PP Nomor 12 Tahun 2021 tentang Perubahan Atas Peraturan Pemerintah No. 14 Tahun 2016 tentang Penyelenggaraan Perumahan dan Kawasan Permukiman; (2) PP No. 14 Tahun 2021 tentang Perubahan Atas Peraturan Pemerintah No. 22 Tahun 2020 tentang Peraturan Pelaksanaan UU Nomor 2 Tahun 2017 tentang Jasa Konstruksi; (3) PP No. 17 Tahun 2021 tentang Perubahan keempat Atas Peraturan Pemerintah No. 15 Tahun 2005 tentang Jalan Tol; (4) PP No. 48 Tahun 2021 tentang Perubahan Ketiga Atas PP No. 31 Tahun 2013 Tentang Peraturan Pelaksanaan UU No. 6 Tahun 2011 tentang Keimigrasian.

12 Dari 4 Perpres yang dibentuk pasca omnibus law, hanya terdapat 1 Perpres yang mengubah Perpres yang lama yaitu; Perpres No. 12 Tahun 2021 tentang Perpres Perubahan Atas Peraturan Presiden Nomor 16 Tahun 2018 tentang Pengadaan Barang/Jasa Pemerintah. 


\section{Omnibus dan Pemerintahan Daerah}

Penerapan metode omnibus dalam UU Pemerintahan Daerah telah berdampak pada 9 pasal pengaturan yang ada di UU Pemerintahan Daerah. Penyajian data dapat dilihat dan diidentifikasi melalui tabel di bawah ini:

Tabel 2: UU Pemerintahan Daerah Pasca Omnibus Law

\begin{tabular}{llc}
\hline No & UU No. 23 Tahun 2014 tentang Pemerintahan Daerah & Jumlah \\
\hline 1 & Jumlah Pasal Terdampak UUCK & \\
2 & Jumlah PP yang masih berlaku akibat perintah UU14 & 9 Pasal \\
3 & Jumlah PP Terdampak UUCK & 25 Peraturan \\
\hline 4 & Jumlah Perpres yang masih berlaku akibat perintah UU15 & 2 Peraturan \\
\hline 5 & Jumlah Perpres Terdampak UUCK & - \\
\hline
\end{tabular}

Hasil identifikasi menunjukan bahwa penerapan metode omnibus dalam UU Cipta Kerja berdampak pada perubahan hubungan kewenangan antara pemerintah pusat dan daerah. Pembentukan dan perubahan pasal-pasal baru dalam UU Cipta Kerja memperkuat sentralisasi ${ }^{16}$ kekuasaan di bawah pemerintah pusat dengan mengatur kembali pembagian urusan dan menebalkan fungsi pengawasan terhadap pemerintah daerah. Hal ini terbaca dari intensi perubahan pasal-pasal dalam UU Cipta Kerja yang menutup ruang kemandirian daerah dan membuka pola ketergantungan yang tinggi terhadap pemerintah pusat. Salah satunya ialah pembagian urusan pemerintahan konkuren antara pusat dan daerah.

13 Terdapat dua Pasal Pembentukan norma baru di Pasal 292 dan Pasal 402 dengan menyisipkan Pasal 292A dan 402A. Sementara ada 7 Pasal yang diubah yaitu Pasal 16, Pasal 250, Pasal 251, Pasal 252, Pasal 260, Pasal 300, dan Pasal 349. Lihat Lebih lengkap lihat dalam UU Nomor 11 Tahun 2020 tentang Cipta Kerja.

14 Dari penelusuran studi dokumen yang dilakukan tim peneliti menunjukkan bahwa masih terdapat kurang lebih 25 Peraturan Pelaksana berupa PP yang lahir dari perintah undang-undang. Beberapa di antaranya seperti PP Pinjaman Daerah, PP BUMD, PP Standar Pelayanan Minimal, PP Satpol PP dan PP Inovasi Daerah.

15 Studi penelusuran dokumen yang dilakukan tim peneliti juga menemukan sebanyak dua Peraturan Pelaksana dalam bentuk Perpres yang juga lahir dari perintah undang-undang. Seperti Peraturan Presiden Nomor 91 Tahun 2015 tentang Dewan pertimbangan Otonomi Daerah dan Peraturan Presiden Nomor 3 Tahun 2018 tentang Pejabat Sekertaris Daerah.

${ }^{16}$ Jauh sebelum pembentukan UU Cipta Kerja, Politik Hukum re-sentralisasi hubungan pusat daerah sebenarnya telah ditegaskan lebih dulu melalui studi Ni'matul Huda dan Despan Heriansyah. Studi ini menunjukan peralihan kekuasaan Presiden Susilo Bambang Yudoyono ke Jokowi yang ditandai dengan pembentukan UU Nomor 23 Tahun 2014 tentang Pemerintahan Daerah mengubah pola otonomi seluas-luasnya menjadi pola hubungan yang menguatkan kembali kuasa pusat atas daerah. Lihat Ni'matul Huda dan Despan Heryansyah, "Kompleksitas Otonomi Daerah Dan Gagasan Negara Federal Dalam Negara Kesatuan Republik Indonesia”, Jurnal Hukum Ius Quia Iustum, Nomor. 2 Vol. 26 Mei 2019, hlm 246. 
Lampiran UU Nomor 23 Tahun 2014 tentang Pemerintahan Daerah telah membagi secara detail urusan pemerintahan konkuren antara pemerintah pusat dengan pemerintahan daerah. Pemerintahan daerah memiliki kewenangan untuk menetapkan peraturan daerah untuk melaksanakan urusan pemerintahan konkuren tersebut. ${ }^{17}$ Namun dengan pemberlakuan UUCK, dominasi pemerintah pusat cenderung menjadi sangat kuat. Sebagai contoh dalam konteks penyederhanaan perizinan. Sentralisasi kuasa perizinan ${ }^{18}$ di bawah pemerintah pusat secara tidak langsung telah menisbihkan hubungan pusat dan daerah yang berlandaskan otonomi luas. Upaya ini sekaligus mereduksi semangat reformasi politik di 1998 yang didesain guna memperkuat politik lokal.19

Tidak berhenti sampai pada pembagian urusan pemerintah pusat dan daerah, pengaturan hubungan pengawasan dalam UU Cipta Kerja juga melahirkan pembacaan hukum yang bersifat represif. Dampak pemberlakuan perda dan perkada yang bertentangan sebagaimana ketentuan yang ditetapkan dalam UU Cipta Kerja bahkan berimplikasi pada sanksi administratif kepada kepala daerah. ${ }^{20}$

Model pengawasan seharusnya tidak boleh berdampak pada sanksi administratif terhadap kepala daerah dan anggota DPRD. Sejauh penelusuran penulis, belum ada legitimasi doktrin yang menguatkan bahwa sanksi administrasi dapat digunakan sebagai imbas atas hubungan pengawasan pemerintah pusat terhadap daerah. Sebab fungsi kontrol atas peraturan daerah sebenarnya cukup dilakukan melalui pengawasan pembentukan produk hukum daerah melalui pemerintah pusat, ${ }^{21}$ maupun melalui judicial review yang dilakukan oleh lembaga peradilan. ${ }^{22}$

${ }^{17}$ Dian Agung Wicaksono dan Faiz Rahman, "Penafsiran terhadap Kewenangan Mengatur Pemerintahan Daerah dalam Melaksanakan Urusan Pemerintahan melalui Pembentukan Peraturan Daerah" Jurnal Negara Hukum: Vol. 11, No. 2, November 2020, hlm. 231

18 Lihat Bagian Ketiga Pemerintahan Daerah Pasal 350 UU Nomor 11 Tahun 2020 Tentang Cipta Kerja. Berdasarkan Pasal tersebut, Kepala daerah wajib memberikan pelayanan Perizinan Berusaha sesuai dengan ketentuan peraturan perundang-undangan dan norma, standar, prosedur, dan kriteria yang ditetapkan oleh Pemerintah Pusat.

${ }^{19}$ Lihat Henk Schulte Nordholt and Gerry Van Klinken, Renegotiting Boundaries, Local politics in Post-Soeharto Indonesia, KITLV Press, 2007, hlm. 1.

${ }^{20}$ Lihat Bagian Ketiga Pemerintahan Daerah Pasal 252 UU Nomor 11 Tahun 2020 tentang Cipta Kerja. Berdasarkan Pasal tersebut, Sanksi administratif dikenakan kepada kepala Daerah dan anggota DPRD berupa tidak dibayarkan hak keuangan selama 3 (tiga) bulan yang diatur dengan ketentuan peraturan perundang-undangan.

21 Dalam hal ini dilakukan melalui koordinasi dan klarifikasi rancangan peraturan daerah oleh Kementerian Dalam Negeri, demikian juga harmonisasi oleh Kementerian Hukum dan HAM, merupakan 
Pemerintahan daerah dalam sistem negara kesatuan adalah sub sistem pemerintahan negara yang tidak mungkin melepaskan sama sekali aspek pengawasan sebagai unsur pengerat ikatan kesatuan. Pengawasan merupakan salah satu instrumen penting untuk mewujudkan bekerjanya sistem tersebut. Pemerintah dengan adanya pengawasan ini dapat melakukan tindakan terhadap pemerintahan daerah yang tidak dapat menjalankan pemerintahan dengan baik. Hanya saja pengawasan oleh Pemerintah semestinya berjalan secara proporsional di bawah ketentuan hukum yang proporsional dan konsisten. Pengawasan yang terlalu kuat juga dapat mengekang daerah dan mengganggu hubungan pusat-daerah. ${ }^{23}$

Hubungan yang sentralistis hanya mampu memakmurkan elite, sedangkan sistem yang desentralistis diharapkan akan dapat meningkatkan kualitas kehidupan sosial, ekonomi dan politik masyarakat. ${ }^{24}$ Pola ini sebenarnya telah disepakati sebagai bagian integral dari tujuan besar re-demokratisasi di masa transisi silam. Bahwa desentralisasi kekuasaan tidak lagi berorientasi pada pemerintah pusat tetapi juga didistribusikan kepada pemerintah daerah. ${ }^{25}$ Jika dibaca dalam lanskap politik dan teknik legislasi, pengundangan cipta kerja jelas digunakan sebagai langkah "bypass" untuk mengubah pola hubungan pemerintah pusat dan daerah tanpa mengubah struktur UU Pemerintahan Daerah.

\section{Omnibus dan Administrasi Pemerintahan}

Penerapan metode omnibus dalam rezim administrasi pemerintahan (adpem) telah berdampak pada 5 pasal pengaturan yang ada di dalam UU Adpem. Penyajian data dapat dilihat dan diidentifikasi melalui tabel di bawah ini:

\footnotetext{
bentuk pengawasan yang dilakukan oleh pemerintah pusat kepada pemerintah daerah. Lihat Bayu Dwi Anggono, Pokok-Pokok Pemikiran Penataan Peraturan Perundang-Undangan di Indonesia, Konpress, Jakarta, 2020, hlm. 247

22 Lihat Pasal 24A ayat (1) UUDN Tahun 1945 Setelah Perubahan.

23 Enny Nurbaningsih, "Berbagai Bentuk Pengawasan Kebijakan Daerah Dalam Era otonomi Luas" Jurnal Mimbar Hukum Volume 23, Nomor 1, Februari 2011, hlm 188.

${ }^{24}$ Lihat Siti Zuhro, "Otoda Dalam UU Pemda Baru: Masalah dan Tantangan Hubungan Pusat dan Daerah”, Jurnal Penelitian Politik | Volume 13 No. 2 Desember 2016, hlm. 214.

${ }^{25}$ Lihat juga analisis Lay yang mentakan bahwa keberhasilan otonomi daerah masih berjalan stagnan akibat dominasi elit, oligarki dan pebisnis. Lihat Cornelis Lay, "Democratic Transition in Local Indonesia-An Overview of Ten Years Democracy", Jurnal Ilmu Sosial dan Ilmu Politik Volume 15, Nomor 3, Maret 2012, hlm. 208
} 
Tabel 3: UU Administrasi Pemerintahan Pasca Omnibus Law

\begin{tabular}{llc}
\hline No & UU No. 30 Tahun 2014 tentang Administrasi Pemerintahan & Jumlah \\
\hline 1 & Jumlah Pasal Terdampak UUCK ${ }^{26}$ & 5 Pasal \\
2 & Jumlah PP yang masih berlaku akibat perintah UU 27 & 1 Peraturan \\
\hline 3 & Jumlah PP Terdampak UUCK & - \\
\hline 4 & Jumlah Perpres yang masih berlaku akibat perintah UU28 & - \\
\hline 5 & Jumlah Perpres Terdampak UUCK & - \\
\hline
\end{tabular}

Pengaturan dalam UU Cipta Kerja memberikan dampak signifikan atas kriteria penggunaan diskresi dalam UU Adpem. Diskresi di dalam UU Cipta Kerja tidak lagi didasarkan atas kesesuaian terhadap ketentuan peraturanperundang-undangan. Metode omnibus menghapus poin b dalam UU Adpem sebagai syarat penerapan diskresi. Dalam artian, penerapan diskresi dibuat lebih longgar sepanjang telah sesuai dengan AUPB, alasan objektif, tanpa konflik kepentingan dan iktikad baik. Mengingat sifat utama diskresi ialah memberikan ruang kebebasan secara doelmatigheid kepada pejabat pemerintahan dalam penyelenggaraan pemerintahan guna kepentingan umum. ${ }^{29}$

Selain penggunaan syarat diskresi, UUCK juga melakukan modifikasi atas ketentuan syarat sahnya keputusan. Menurut Pasal 53 UU Adpem, secara prinsip mengatur apabila dalam batas waktu yang ditentukan (10 hari kerja), Badan atau Pejabat Pemerintahan tidak mengeluarkan dan/atau melakukan keputusan dan/atau tindakan, maka permohonan tersebut dianggap dikabulkan secara hukum. Dalam keputusan fiktif positif ini, pemohon tidak secara otomatis memperoleh hasil permohonannya, akan tetapi harus terlebih dahulu mengajukan permohonan kepada Pengadilan Tata Usaha Negara untuk memperoleh putusan penerimaan permohonan..$^{30}$ Batas waktu yang ditentukan dipangkas hingga lima hari kerja tanpa

${ }^{26}$ Terdapat dua Pasal Pembentukan norma baru yaitu di Pasal 19 dan 39 dengan menyisipkan Pasal 19A dan Pasal 39A. Kemudian terdapat tiga Pasal yang diubah yaitu Pasal 24, Pasal 39, dan Pasal 53. Lihat UU Nomor 11 Tahun 2020 tentang Cipta Kerja.

27 Dari penelusuran studi dokumen yang dilakukan tim peneliti menunjukkan bahwa terdapat satu peraturan pelaksana yang lahir dari perintah undang-undang yaitu Peraturan Pemerintah Nomor 48 Tahun 2016 tentang Tata Cara Pengenaan Sanksi Administratif Kepada Pejabat Pemerintahan.

${ }_{28}$ Dalam UU Administrasi Pemerintahan tim peneliti tidak menemukan adanya perintah undang-undang yang memerintahkan pembentukan peraturan pelaksana dalam bentuk Peraturan Presiden.

${ }^{29}$ H.M. Laica Marzuki, "Menyoal Diskresi yang Terpasung (Mengkritisi Undang -Undang Administrasi Pemerintahan)", Journal Amanna Gappa Vol. 25, No. 2 September 2017, hlm. 1-6.

${ }^{30}$ Ridwan et all, "Perluasan Kompetensi Absolut Pengadilan Tata Usaha Negara dalam Undang-Undang Administrasi Pemerintahan” Jurnal Hukum Ius Quia Iustum, No. 2 Volume. 25 Mei 2018, hlm. 349 
putusan penetapan PTUN, melainkan cukup dengan Peraturan Presiden. ${ }^{31}$ Semangat penyederhanaan perizinan menjadi garis besar politik hukum dalam UU Cipta Kerja. Presiden diletakkan sebagai episentrum kekuasaan dalam menentukan dan menetapkan izin, standar, dispensasi dan/konsesi.

Upaya ini bukan berarti tidak melahirkan problem. Dalam hal pemberian izin misalnya, pendekatan Regulasi Berbasis Risiko (RBR) ${ }^{32}$ dalam UU Cipta Kerja perlu diberikan garis penekanan. Dalam hal ini, paradigma pemberian izin didasarkan hanya pada jenis usaha yang memiliki risiko tinggi. Penelitian yang dilakukan Al'afgani dan Bisariyadi menjadi sangat menarik.

UU Cipta Kerja belum berhasil mengalkulasi dampak risiko yang bersifat volatil dan sistemik. Risiko volatil merupakan risiko yang dapat berubah, tadinya tinggi kemudian menjadi rendah maupun sebaliknya. Contohnya dalam polusi pada air. Bahaya yang ditimbulkan dari polusi tersebut bervariasi tergantung musim. Ketika musim kering misalnya, risikonya menjadi lebih tinggi dibanding pada musim lainnya. Sementara Risiko sistemik adalah resiko yang kecil apabila dilihat per individu atau kegiatan tetapi akan menjadi besar karena kecenderungannya yang dilakukan oleh banyak pihak. Sebagai contoh dari resiko sistemik adalah penyedotan air tanah di pemukiman dan penggunaan pestisida oleh petani. Apabila dilakukan secara perorangan, dampak dari kegiatan tersebut kepada secara masif dampaknya juga akan besar. Penyedotan air tanah dapat menimbulkan amblesnya muka tanah dan intrusi air laut. Demikian juga dengan penggunaan pestisida dan pupuk dalam pertanian yang dilakukan secara masif maka akan menyebabkan tercemarnya kualitas air. Rusaknya air tanah dan air permukaan akibat abstraksi dan polusi bersifat sistemik. ${ }^{33}$

Dapat dibayangkan, perubahan konsep fiktif positif dengan menghilangkan peran badan peradilan dalam dalam penetapan izin, justru dapat mengurangi Kerja.

31 Lihat Bagian Kedua Administrasi Pemerintahan Pasal 53 UU Nomor 11 Tahun 2020 tentang Cipta

${ }^{32}$ Konsep RBR dalam penyederhanaan perizinan karena diasumsikan penerapan RBR bertujuan untuk memangkas jumlah perizinan yang ada. Pemberian izin hanya diutamakan kepada jenis usaha yang memiliki risiko tinggi. Sementara izin usaha dengan risiko menengah dan rendah cukup dengan sertifikat standar dan pendaftaran nomor induk berusaha. Lihat Bagian Peningkatan ekosistem investasi dan kegiatan berusaha, Pasal 7 UU Nomor 11 Tahun 2020 tentang Cipta Kerja.

33 Mohamad Mova Al Afghani dan Bisariyadi, "Konsep Regulasi Berbasis Risiko: Telaah Kritis dalam Penerapannya pada Undang-Undang Cipta Kerja" Jurnal Konstitusi, Volume 18, Nomor 1, Maret 2021, hlm. 8081. 
kontrol terhadap pemerintah sekaligus mensegregasi pelindungan dan pemenuhan atas HAM. Penulis menilai, metode omnibus telah mengubah paradigma pelayanan publik dari yang bersifat tertib administratif ke arah efisiensi birokrasi. Namun harus diakui di era Jokowi-Ma'ruf, sebenarnya telah terjadi shifting terhadap paradigma "good govenrnance" dari prinsip penghormatan, pemenuhan, dan perlindungan HAM kemudian bergerak ke arah ramah pasar "friendly market". Analisis ini sebenarnya telah dinukilkan lebih dulu oleh studi Wiratraman yang menegaskan bahwa orientasi good governance di Indonesia pada prinsipnya jauh lebih tunduk pada kepentingan "pebisnis" dibanding dengan pemenuhan dan perlindungan HAM. ${ }^{34}$

\section{Omnibus dan Pemerintahan Desa}

Penerapan metode omnibus dalam konteks pemerintahan desa telah berdampak pada 2 pasal pengaturan yang ada di dalam UU Desa dan satu PP pelaksana UU Desa, Penyajian data dapat dilihat dan diidentifikasi melalui tabel di bawah ini:

Tabel 4: UU Pemerintahan Desa Pasca Omnibus Law

\begin{tabular}{llc}
\hline No & \multicolumn{1}{c}{ UU No. 6 Tahun 2014 tentang Pemerintahan Desa } & Jumlah \\
\hline 1 & Jumlah Pasal Terdampak UUCK 35 & 2 Pasal \\
2 & Jumlah PP yang masih berlaku akibat perintah UU 36 & 1 Peraturan \\
\hline 3 & Jumlah PP Terdampak UUCK 37 & 1 Peraturan \\
\hline 4 & Jumlah Perpres yang masih berlaku akibat perintah UU38 & - \\
\hline 5 & Jumlah Perpres Terdampak UUCK & - \\
\hline
\end{tabular}

Berdasarkan data di atas, metode omnibus telah mengubah ketentuan umum kelembagaan Badan Usaha Milik Desa (BUM Desa) dari badan usaha ${ }^{39}$ menjadi

\footnotetext{
${ }^{34}$ Herlambang P. Wiratraman, "Neo-Liberalisme, Good Governance dan Hak Asasi Manusia", Jurnal Hukum Jentera XV, Januari-Maret 2007, hlm. 8-9

35 Terdapat dua Pasal yang diubah yaitu Pasal 1 Angka 6 dan Pasal 87. Lihat UU Nomor 11 Tahun 2020 tentang Cipta Kerja.

36 Peraturan Pemerintah Nomor 11 Tahun 2019 Tentang Perubahan Kedua Atas Peraturan Pemerintah No 43 Tahun 2014 Tentang Peraturan Pelaksanaan Undang-Undang Nomor 6 Tahun 2014 tentang Desa.

${ }^{37}$ Lihat Peraturan Pemerintah No 43 Tahun 2014 tentang Peraturan Pelaksanaan Undang-Undang Nomor 6 Tahun 2014 tentang Desa khusunya yang mengatur tentang Bumdes. PP ini terdampak dengan adanya Perpres Nomor 11 Tahun 2021 tentang Badan Usaha Milik Desa, namun tidak mencabut keberlakuan PP Nomor 43 Tahun 2014.

38 UU pemerintah Desa tidak memberikan perintah pembentukan Pepres sebagai peraturan pelaksana.

39 BUM Desa adalah badan usaha yang seluruh atau sebagian besar modalnya dimiliki oleh Desa melalui penyertaan secara langsung yang berasal dari kekayaan Desa yang dipisahkan guna mengelola aset, jasa pelayanan, dan usaha lainnya untuk sebesar- besarnya kesejahteraan masyarakat Desa. Lihat Pasal 1 Angka 6 UU Nomor 6 Tahun 2014 tentang Desa.
} 
entitas badan hukum. ${ }^{40}$ Kemudian juga terdapat perubahan di dalam Pasal 87 UU Desa. Melalui metode omnibus, pasal ini kemudian disisipkan angka baru dengan menegaskan bahwa BUM Desa dapat membentuk unit usaha berbadan hukum sesuai dengan kebutuhan dan tujuan. ${ }^{41}$ Kehadiran BUM Desa yang sejak awal dinisiasi melalui UU Desa merupakan terobosan yang patut diapresiasi dalam rangka pemberdayaan dan penguatan sosio-ekonomi masyarakat desa. 42 Tujuannya tidak lebih sebagai upaya untuk memajukan roda perekonomian masyarakat desa dan mengatasi kesenjangan pembangunan nasional.

Sebagai self governing communities yang bersifat otonom dan mandiri, ${ }^{43}$ desa tetap dituntut untuk mendorong BUM Desa sebagai badan hukum agar memiliki legalitas dalam melakukan hubungan hukum. Hal ini sejalan dengan apa yang dinyatakan oleh Jimly Asshiddiqie, bahwa dampak dari globalisasi desa itu salah satunya adalah terjadinya proses universalisasi nilai-nilai ideal dalam perikehidupan bersama umat manusia, termasuk di desa-desa di seluruh dunia. Meski setiap lokalitas pasti ada ciri khasnya masing-masing, tetapi universalisasi nilai tidak terhindarkan. ${ }^{44}$ Begitu juga dalam hal penguatan kapasitas kelembagaan BUM Desa. Pengaturan ini berdampak secara langsung terhadap pembentukan peraturan pelaksana melalui Perpres No. 11 Tahun 2021 tentang Badan Usaha Milik Desa. Kehadiran Perpres tersebut mengubah beberapa ketentuan dalam Peraturan Pemerintah No. 43 Tahun 2014 tentang Peraturan Pelaksanaan Undang-Undang No. 6 Tahun 2014 tentang Desa khusunya yang mengatur tentang BUM Desa.

40 Bahwa Badan Usaha Milik Desa, yang selanjutnya disebut BUM Desa, adalah "Badan Hukum yang didirikan oleh desa dan/atau bersama desa-desa guna mengelola usaha, memanfaatkan aset, mengembangkan investasi dan produktivitas, menyediakan jasa pelayanan, dan/atau menyediakan jenis usaha lainnya untuk sebesar- besarnya kesejahteraan masyarakat desa". Lihat perubahannya dalam Bagian Badan Usaha Milik Desa, Pasal 1 Angka 6 UU Nomor 11 Tahun 2020 tentang Cipta Kerja.

${ }^{41}$ Lihat dalam Bagian Badan Usaha Milik Desa, Pasal 87 Angka 4 UU Nomor 11 Tahun 2020 tentang Cipta Kerja.

${ }^{42}$ Lihat Ni'matul Huda, Hukum Pemerintahan Desa Dalam Konstitusi Indonesia Sejak Kemerdekaan Hingga Era Reformasi, Setara Press, Malang, 2015, hlm 237.

${ }^{43}$ Lihat Jimly Ashhiddiqie, Konstitusi Dan Konstitusionalisme Indonesia, Sinar Grafika, Jakarta, 2011, hlm. 242

44 Jimly Ashhiddiqie, Gagasan Konstitusi Sosial; Institusionalisasi dan Konstitutusionalisasi Kehidupan Sosial Masyarakat Madani, LP3ES, Jakarta, 2015, hlm. 361. 


\section{Inkompatibilitas Omnibus dalam Penyederhanaan Regulasi}

Berdasarkan data di atas, jika metode omnibus dianggap mampu mengefisiensi legislasi dari segi proses, maka hal itu dapat dibenarkan. Namun, jika diasumsikan mampu menyederhanakan beban regulasi maka itu menjadi lain soal. Ada tiga alasan besar yang menurut hasil penelitian ini menunjukan bahwa metode omnibus tidak kompatibel dalam menyederhanakan beban regulasi.

\section{Ketidakjelasan Ambang Batas Regulasi}

Sebenarnya apa yang hendak dijadikan indikator bahwa kuantitas regulasi mengalami pembengkakan atau "obesitas regulasi". Jika Naskah Akademik (NA) UUCK selalu menitikberatkan bahwa metode omnibus mampu memangkas beban regulasi dari segi jumlah, maka berapa ambang batas kenormalan itu. Silogisme yang dibangun melalui NA setidaknya masih sangat terbuka untuk diperdebatkan lebih jauh. Bila diibaratkan dengan anatomi tubuh manusia, seseorang dapat dikatakan obesitas jika melebihi ambang batas berat tertentu. Begitupun dalam konteks regulasi. Dengan peta jumlah regulasi yang disajikan pada bab pendahuluan di atas, pemerintah juga sebanarnya belum mampu mengolah data yang ada, sehingga tidak ada instrumen secara kuantitatif untuk mengukur kapastitas regulasi nasional ataupun daerah.

Sungguhpun pemerintah telah memiliki skala ambang batas, dimana letak pembengkakan itu terjadi? Jumlah regulasi di tingkat undang-undang (dikenal dengan istilah "primary legislation") ataukah peraturan di bawah undang-undang (dikenal dengan istilah "delegated legislation"). ${ }^{45}$ Hal ini juga belum terbaca dan terjawab oleh pembentuk undang-undang dan konsep yang ditawarkan dalam NA UU CK. Di satu sisi, isu seputar hiper-regulasi merupakan hal penting yang perlu direspons dalam praktik legislasi di Indonesia. Namun di sisi yang lain, sistem perundang-undangan di Indonesia juga perlu memiliki instrumen dan tolak ukur kapan sebuah peraturan perundang-undangan mengalami

${ }^{45}$ Dalam lanskap praktik legislasi, Asshiddiqie membedakan dua istilah tersebut untuk menegaskan bahwa hubungan legislator dan legislasi memiliki dua tingkatan. Tingkatan pertama disebut "primary" yang menitikberatkan pada hubungan Presiden dan DPR dalam membentuk undang-undang. Sementara secondary atau delegated ialah produk peraturan perundang-undangan yang lahir di bawah undang-undang. Legislatornya bisa berasal dari pemerintah, maupun alat kelengakapan daerah seperti kepala daerah dan Dewan Perwakilan Rakyat Daerah (DPRD). Lihat Jimly Asshiddiqie, Perihal Undang-Undang, Rajawali Press, Jakarta, 2010, hlm. 262. 
pembengkakan. Tanpa adanya skala ambang batas, isu hiper regulasi akan terus muncul sebagai wacana yang tak berujung.

Sistem perundang-undangan yang diadopsi dalam tahapan perencanaan justru sangat kontraproduktif dengan upaya untuk merampingkan dan menyederhanakan regulasi. Hal ini dapat diidentifikasi dari target program legislasi nasional yang selalu dititik tekankan pada volume atau jumlah RUU yang akan menjadi target legislasi secara berkala. Bahkan ironisnya, tolak ukur keberhasilan legislasi di Indonesia masih dimaknai pada capaian kuantitatif terhadap realisasi capaian Prolegnas. Hal ini dapat dilacak dari narasi pertanggungjawaban ketua DPR dalam sidang tahunan yang selalu mengedepankan capaian kinerja secara kuantitatif, bukan secara kualitatif. ${ }^{46}$ Studi Wintgens menegaskan bahwa dalam praktik legislasi di sebuah negara, kuantitas dan kualitas adalah indikator utama keberhasilan pembentukan peraturan perundang-undangan. ${ }^{47}$

Sementara performa kelembagaan legislator khususnya pasca reformasi, kecenderungannya masih berkutat pada kuantitas di banding kualitas. Pendekatan penyelesaian problem sosial masih sangat bertumpu pada pendekatan yang bersifat "state-oriented". Regulasi masih dipandang sebagai obat paling mustajab dalam menyelesaikan problem sosial. Tidak heran jika Prolegnas selalu memunculkan ledakan jumlah atau volume legislasi yang tinggi tanpa disertai dengan kapasitas kelembagaan yang mumpuni. ${ }^{48}$ Hasil identifikasi The Organization for Economic Co-operation and Development (OECD) menunjukan salah satu problem mendasar kinerja legislasi di Indonesia disebabkan minimnya alat atau instrumen untuk mengukur dan mengelola peraturan perundang-undangan di Indonesia. "Indonesia does not, however, have an explicit 'whole-of-government' policy to ensures ispiquality in regulation and regulatory management". 49

Isu perampingan dan penyederhanaan regulasi oleh karenanya menjadi sangat utopis dalam kerangka sistem perundang-undangan di Indonesia. Jika

\footnotetext{
46 Lihat Bayu Dwi Anggono, Perkembangan Pembentukan Undang-Undang di Indonesia, Konpress, Jakarta, 2014, hlm. 233.

${ }^{47}$ Luc J. Wintgens (ed), Legislation in Context: Essay in Legishprudence, Ashgate E-Book, U.K. 2007, hlm. ix.

${ }^{48}$ Lihat Idul Rishan, "Risiko Koalisi Gemuk Dalam Sistem Presidensil", Jurnal Ius Quia Iustum, No. 2 Vol. 27 Mei, 2020, hlm. 232.

49 Organization for Economic Co-operation and Development, Reviews of Regulatory Reform, Government Capacity to Assure High Quality Regulation, OECD, September, 2012, hlm. 19.
} 
legislator memiliki komitmen dalam menekan beban volume peraturan perundang-undangan, kendali kuantitas dengan model ambang batas seharusnya bisa menjadi upaya untuk mencegah beban hiper-regulasi. Belanda ${ }^{50}$ misalnya, melakukan beberapa tahapan kebijakan reformasi regulasi melalui kontrol kuantitas regulasi.

\section{Omnibus sebagai Teknik Penyederhanaan Legislasi}

Hasil pengolahan data sekunder memperlihatkan, metode omnibus merupakan teknik untuk menyederhanakan legislasi, bukan sebagai upaya penyederhanaan regulasi. Ada kekaburan persepsi yang diidentifikasi penulis dalam NA UU CK. Miskonsepsi ini terjadi ketika cetak biru RUU Cipta Kerja yang menggunakan metode omnibus dianggap sebagai solusi dalam menyederhanakan regulasi. Begitupun dalam beberapa studi terdahulu yang menegaskan bahwa metode omnibus merupakan upaya untuk merampingkan atau menyederhanakan regulasi. Baik secara konseptual maupun penyajian data sekunder yang dianalisis pada sub bab di atas, menunjukan bahwa teknik omnibus tidak pernah menyederhanakan regulasi dari segi jumlah.

Pertama, penulis akan memulai analisis dengan menggunakan pendekatan konseptual. Di berbagai negara yang telah mengadopsi metode omnibus, metode ini pada dasarnya digunakan sebagai teknik perumusan undang-undang yang disusun untuk sekaligus mengubah ketentuan beberapa pengaturan di dalam sebuah undang-undang. Data sekunder ini diperoleh dan diolah dari pendapat hukum $^{51}$ dan hasil-hasil studi ${ }^{52}$ yang memiliki relevansi tentang tema besar metode omnibus. ${ }^{53}$ Bahwa penyususnan produk hukum dengan teknik omnibus

\footnotetext{
${ }^{50}$ Lihat Ahmad Redi an Ibnu Sina Chandranegara (Ed), Omnibus Law: Diskursus Pengadopsiannya Ke dalam Sistem Perundang-undangan Nasional, Rajawali Pers, Jakarta, 2020, hlm. 44.

51 Ahsin Thohari mengartikan omnibus law sebagai teknik pembentukan undang-undang secara terpadu. Teknik ini memungkinkan dalam satu rancangan undang-undang berisi perubahan atau penggantian beberapa undang-undang sekaligus untuk diajukan ke parlemen untuk dimintakan persetujuan dalam satu kesempatan pengambilan keputusan. Lihat A. Ahsin Thohari, "Menakar Omnibus Law", Opini Harian Koran Sindo, 30 Oktober 2019, hlm 6.

52 Adam M Dodek mendefinisikan Omnibus law sebagai suatu metode untuk mengubah isi undangundang ke dalam satu undang-undang guna mewujudkan harmonisasi di setiap level peraturan Lihat Adam M Dodek, "Omnibus Bills: Constitutional Constraints and Legislative Deliberation", Ottawa Law Review Vol. 48 Issue 1, 2017, hlm 12.

${ }^{53}$ Louis Massicote menuliskan bahwa omnibus dimaknai sebagai relating to or dealing with numerous objects or items at once; including many things or having various purposes. Lihat Louis Massicotte, "Omnibus Bills in Theory and Practice", Parliamentary Review Vol. 13, No. 1, 2013, hlm. 14.
} 
akan mengenyampingkan beberapa undang-undang yang terkait dan beririsan dengan satu sama lainnya. Penyampingan beberapa undang-undang dilakukan agar tujuan dari pembuatan undang-undang dengan metode omnibus dapat tercapai tanpa biaya yang besar. ${ }^{54}$ Menurut Jimly Asshiddiqie, dari segi waktu dan proses, metode ini jelas dapat menyederhanakan teknik legislasi. Sebab jika ditempuh melalui prosedur yang normal, cenderung akan memakan waktu dan perdebatan yang alot. Belum lagi perubahan undang-undang menggunakan sistem "single subject rule" atau perubahan hanya dimungkinkan pada satu jenis pengaturan. 55

Satu undang-undang dengan metode omnibus dapat mengubah banyak undang-undang sekaligus dengan mengubah bagian-bagian tertentu tanpa merusak struktur undang-undang yang lama. Dari segi proses, waktu, dan beban anggaran, jelas metode omnibus sangat efisien digunakan untuk mengubah ketentuan secara multisektoral. Artinya metode omnibus menjadi salah satu alternatif teknik penyederhanaan legislasi, bukan dalam hal menyederhanakan regulasi. Dalam artian, tahapan pengajuan, pembahasan, persetujuan, pengesahan dan pengundangan dapat dilakukan dalam satu undang-undang, sekalipun, menyasar lebih dari satu bahkan lebih ketentuan pengaturan dalam undangundang yang berbeda.

Kedua, melalui random sampling terhadap klaster administrasi pemerintahan menunjukan bahwa pengaturan ke dalam UU Pemerintah Daerah, UU Administrasi Pemerintahan dan UU Desa hanya mengubah dan atau menyisipkan beberapa ketentuan pasal baru ke dalam UU CK. Artinya, metode omnibus tidak dalam kapasitas mencabut undang-undang yang lama melainkan hanya mengubah beberapa pasal-pasal tertentu ke dalam satu undang-undang. Begitupun dalam konteks secondary legislation, turunan pengaturan UU CK dalam bentuk PP dan Perpres tidak mencabut keberadaan peraturan pelaksana yang lama. Artinya, tidak terjadi re-shaping atas struktur peraturan perundangundangan yang ada.

\footnotetext{
${ }^{54}$ Lihat Ibnu Sina Chandranegara, "Kompabilitas Penggunaan Metode Omnibus Dalam Pembentukan Undang-Undang”, Jurnal Hukum Ius Quia Iustum No. 2 Vol. 27 Mei 2020, hlm. 250.

${ }^{55}$ Lihat Jimly Asshiddiqie, Omnibus Law dan Penerapannya di Indonesia, Konpress, Jakarta, 2020, hlm. 7.
} 
Konsekuensi logis yang kemudian ditimbulkan, secara matematis sebenarnya tidak terjadi pengurangan kuantitas terhadap volume regulasi sebagaimana yang dibayangkan di dalam perumusan NA UU CK maupun beberapa studi-studi terdahulu. Beberapa UU yang terdampak omnibus cipta kerja tetap memiliki kekuatan mengikat sepanjang pasal-pasal yang ada di dalamnya tidak mengalami perubahan. Hal ini berlaku secara mutatis mutandis terhadap pertauran pelaksana di bawah undang-undang yang melibatkan PP maupun Perpres. Justru, kehadiran omnibus cipta kerja secara metodologis kembali menambah volume regulasi khususnya pada skala secondary legislation.

\section{Sinkronisasi dan Daya Tambah Regulasi}

Berdasarkan penyajian data di atas, UU Cipta Kerja memiliki permasalahanpermasalahan krusial apabila ditinjau dari aspek metodologis dalam upaya menyederhanakan regulasi yang diasumsikan telah membengkak dan tidak efisien. Persoalan over-regulated yang telah dijustifikasi dalam naskah akademik tidak akan terselesaikan karena pada dasarnya UU Cipta Kerja tidak mencabut dan mengganti keberlakuan UU yang lama. Begitupun jika mencermati aturan turunan yang sangat berpotensi kembali melahirkan kebutuhan sinkronisasi dan daya tambah volume regulasi yang sangat kompleks. ${ }^{56}$

Perlu diingat, Maria Farida Indarti menerjemahkan omnibus law sebagai satu undang-undang yang mengandung atau mengatur berbagai macam substansi dan berbagai macam subjek untuk langkah penyederhanaan dari berbagai undang-undang yang masih berlaku. Menurutnya, omnibus law tidak dapat disamakan dengan keberlakuan undang-undang payung yaitu undang-undang yang merupakan induk dari undang-undang lain sehingga kedudukannya lebih tinggi dari undang-undang anaknya. Mengingat undang-undang payung inilah yang melimpahkan pengaturan lebih lanjutnya secara delegasi pada undangundang lain. 57

Membaca kecenderungan di atas, maka kebutuhan sinkronisasi perundangundangan akan menjadi cukup kompleks. Pertama, tentu sinkronisasi dalam level

${ }^{56}$ Bandingkan dengan hasil kajian Fakultas Hukum UGM atas pembentukan UU Cipta Kerja. Lihat Sigit Riyanto et al, 2020, Ringkasan Eksekutif Kertas Kebijakan Catatan Kritis Terbadap UU Nomor 11 Tabun 2020 tentang Cipta Kerja, Fakultas Hukum Universitas Gadjah Mada, Yogyakarta, hlm. 3.

${ }^{57}$ Lihat Maria Farida Indrati, “Omnibus Law UU Sapu Jagat”, Opini Harian Kompas, 4 Januari 2020, hlm. 6 
undang-undang. Hal ini tidak mudah dilakukan karena status UU Cipta Kerja yang menggunakan metode omnibus tidak dicabut atau tetap memiliki kekuatan hukum mengikat sepanjang pasal-pasal yang ada di dalamnya tidak mengalami perubahan. Sementara di lain hal, UU yang terdampak akan sangat dimungkinkan masuk dalam daftar UU yang akan dibahas dan diubah dalam prolegnas ataupun prolegnas prioritas.

Penulis akan mensimulasikan jika pasca pengundangan UUCK, UU Pemda, UU Adpem, dan UU Desa masuk dalam prolegnas prioritas yang akan mengalami perubahan. Kebutuhan sinkronisasi itu menjadi sangat kompleks. Sebab, metode omnibus dan UU secara hierarkis memiliki tingkat kedudukan yang sama dalam peraturan perundang-undangan. Sifat cair ${ }^{58}$ dan dinamis ${ }^{59}$ dalam pembentukan atau perubahan UU membuka peluang terjadinya overlapping antara pengaturan di dalam UUCK dan perubahan pada UU terdampak.

Berkaca pada kecenderungan demikian, maka tidak menutup kemungkinan pengaturan di dalam perubahan UU yang lama kembali mengatur beberapa ketentuan yang sebenarnya sudah diatur dengan UUCK. Potensi terjadinya redundancy dalam praktik legislasi pasca pengundangan cipta kerja menjadi sangat besar. Oleh karenanya, ancaman terjadinya disharmonisasi pada omnibus cipta kerja dengan UU terdampak (UU Pemda, UU Adpem, dan UU Desa) yang akan mengalami perubahan menjadi sangat potensial memicu ketidakpastian hukum dan tumpang tindih pengaturan di level undang-undang. Anasir ini sudah lebih dulu dinukilkan oleh Keyzer bahwa metode omnibus berisiko melahirkan kebutuhan snkronisasi yang kompleks. ${ }^{60}$

Kedua, soal daya tambah regulasi di sektor peraturan pelaksana. Harapan awal yang diproyeksikan akan me-reshaping struktur regulasi praksis menjadi tidak tercapai. UUCK justru memicu gejala over-delegasi ke dalam peraturan pelaksana. Dari data yang diperoleh melalui Pusat Studi Hukum dan Kebijakan

58 Larry Alexander yang menilai hukum terbentuk melalui penalaran politik. Proses dan kepentingan politik menentukan bagaimana hukum terbentuk dan mengikat sebagai norma. Lihat Larry Alexander, "Law and Politics: What is Their Relation", Harvard Journal of Law \& Public Policy, Volume 41 Issue 1, January 2018, hlm. $355 \& 356$.

${ }^{59}$ Unger juga melihat hukum sebagai bagian dari titik temu kompromi politik dari beragam kepentingan. Lihat Roberto Mangabeira Unger, The Critical Legal Studies Movement, Verso, United Kingdom, 2015, hlm. 191.

60 Patrick Keyzer, "The Indonesian Omnibus Law: Opportunities and Challenges", Makalah Materi Kuliah Umum, Universitas Brawijaya, Malang, 29 January 2020, hlm. 2. 
Indonesia (PSHK) menemukan sekitar 466 ketentuan delegasi pasca pengundangan UUCK. Ketentuan itu berupa 11 delegasi ke peraturan pemerintah, 11 ke peraturan presiden, 377 ke peraturan menteri, 60 peraturan lembaga pemerintah non-kementerian, dan 7 peraturan daerah. ${ }^{61}$

\section{Gambar :1 Prosentase Besaran Delegasi Pengaturan dalam UUCK}

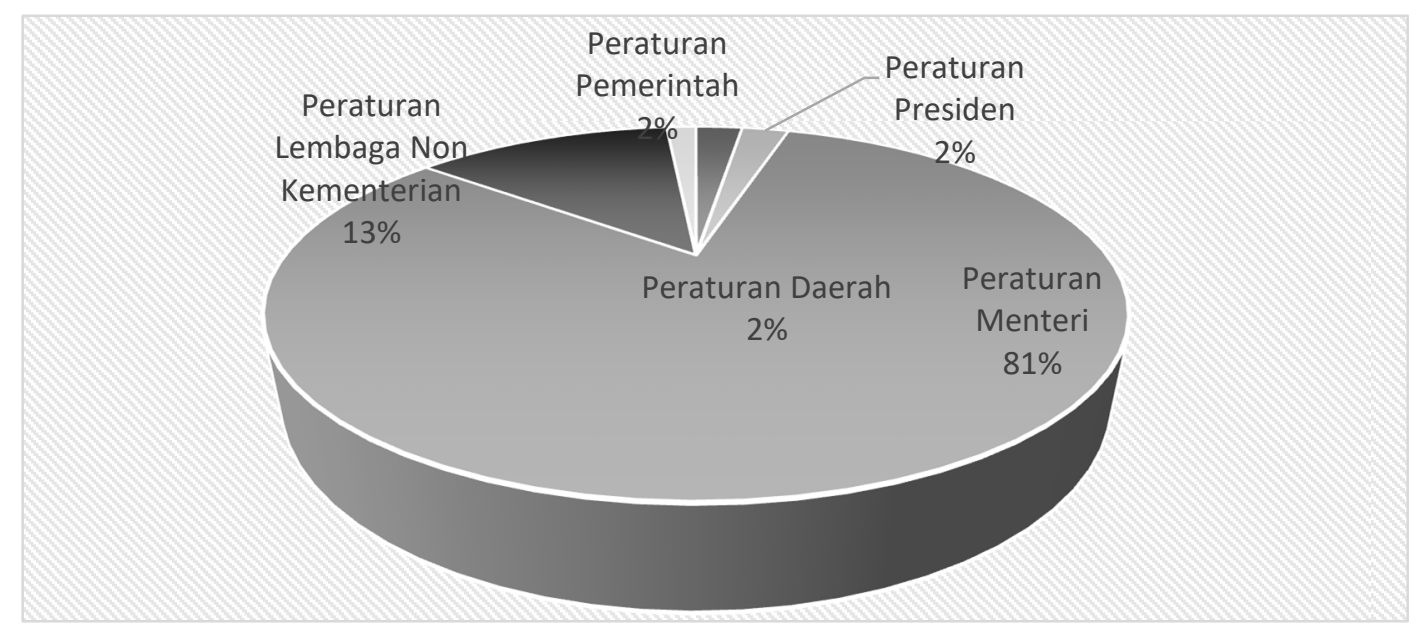

Di dalam perspektif ilmu perundang-undangan, gejala di atas tidak dapat dibenarkan karena tiga alasan. Pertama, sifat peraturan menteri tidak dalam kapasitas untuk mengatur ke luar. Kedua, dari perspektif ilmu perundangundangan, Peraturan Lembaga Non Kementerian dan Peraturan Menteri belum memiliki padanan yang definitif baik dari segi materi muatan maupun kedudukannya dalam hierarki peraturan perundang-undangan. Jika kedua produk tersebut ditafsirkan setingkat Peraturan Pemerintah, maka kebutuhan sinkronisasi pada level peraturan daerah menjadi sangat kompleks. Ketiga, memberikan ruang pengaturan yang besar pada level peraturan menteri justru akan menjauhkan semangat dalam menekan volume regulasi. Berkaca pada gambar dan data di atas, pengundangan UUCK jelas tidak kompatibel dalam melakukan penyederhanaan regulasi.

\section{Penutup}

Berdasarkan hasil penyajian data dan analisis, penelitian ini menyimpulkan dua hal. Pertama, perihal penerapan metode omnibus di Indonesia. Metode

${ }^{61}$ Antoni Putra, "Ironi Penyederhanaan Regulasi”, Opini Koran Tempo, 17 Maret 2021, hlm. 10. 
omnibus yang digunakan dalam perumusan UU CK merupakan teknik untuk mengefisiensi praktik legislasi dari sisi proses. Total terdapat 11 klaster pengaturan dalam UU CK dengan 81 undang-undang terdampak dan 2 undangundang yang dicabut. Sampai dengan studi ini diselesaikan, metode omnibus telah melahirkan 47 PP dan 4 Perpres. Dalam klaster administrasi pemerintahan yang dijadikan sampel studi penulis, menunjukan terhadap tiga undang-undang terdampak (UU Pemda, UU Adpem, dan UU Desa) tetap memiliki kekuatan hukum mengikat, sepanjang tidak mengalami perubahan melalui UU CK. Hal ini berlaku secara mutatis mutandis terhadap turunan pengaturan UU terdampak. Secara materil, beberapa perubahan dalam UU Desa membawa dampak positif terhadap perekonomian masyarakat desa. Namun beberapa pengaturan yang berdampak pada pemerintah daerah dan administrasi pemerintahan kenyataanya telah mengubah politik hukum hubungan pusat dan daerah ke arah yang lebih sentralistis.

Kedua, inkompatibilitasnya terhadap upaya penyederhanaan regulasi. Hipotesa yang menguat melalui hasil-hasil studi terdahulu dan perumusan naskah akademik menyatakan, metode omnibus memiliki daya guna untuk menyederhanakan regulasi. Tidak ada korelasi antara kegunaan metode omnibus dengan upaya penyederhanaan regulasi. Ada tiga poin besar yang menurut hasil penelitian ini menunjukan bahwa metode omnibus tidak kompatibel dalam menyederhanakan regulasi. (1) ketiadaan indikator ambang batas kenormalan atau tolak ukur kapan volume regulasi dalam sistem perundang-undangan di Indonesia membengkak atau dikualifikasikan sebagai hiper-regulated (2) metode omnibus lebih kompatibel digunakan sebagai teknik penyederhanaan legislasi, bukan menyederhanakan atau merampingkan struktur regulasi, dan (3) metode omnibus melahirkan kebutuhan sinkronisasi regulasi yang cukup kompleks dan potensial menambah volume regulasi pada tataran implementasi. Oleh karenanya, hasil penelitian ini sampai pada satu titik persepsi kesimpulan bahwa penggunaan metode omnibus yang diterapkan dalam UU Cipta Kerja sama sekali tidak berhasil me-reshaping strukur regulasi melainkan justru menambah volume regulasi. 


\section{Daftar Pustaka}

\section{Buku}

Anggono, Bayu Dwi, Pokok-Pokok Pemikiran Penataan Peraturan PerundangUndangan di Indonesia, Konpress, Jakarta, 2020.

Perkembangan Pembentukan Undang-Undang di Indonesia, Konpress, Jakarta, 2014.

Asshiddiqie, Jimly, Omnibus Law dan Penerapannya di Indonesia, Konpress, Jakarta, 2020.

, Perihal Undang-Undang, Rajawali Press, Jakarta, 2010.

, Konstitusi Dan Konstitusionalisme Indonesia, Sinar Grafika, Jakarta, 2011.

Gagasan Konstitusi Sosial; Institusionalisasi dan Konstitutusionalisasi Kehidupan Sosial Masyarakat Madani, LP3ES, Jakarta, 2015.

Huda, Ni'matul, Hukum Pemerintahan Desa Dalam Konstitusi Indonesia Sejak Kemerdekaan Hingga Era Reformasi, Setara Press, Malang, 2015.

Redi Ahmad \& Chandranegara, Ibnu Sina, (Ed), Omnibus Law: Diskursus Pengadopsiannya Ke dalam Sistem Perundang-undangan Nasional, Rajawali Pers, Jakarta, 2020.

Schulte, Henk Nordholt \& Klinken, van Gerry, Renegotiting Boundaries, Local politics in Post-Soeharto Indonesia, KITLV Press, 2007.

Unger, Roberto Mangabeira, The Critical Legal Studies Movement, Verso, United Kingdom, 2015.

Wintgens, Luc J., (ed), Legislation in Context: Essay in Legislprudence, Ashgate EBook, U.K.2007.

\section{Jurnal}

Antoni Putra, "Penerapan Omnibus law Dalam Upaya Reformasi Regulasi", "Jurnal Legislasi Indonesia, Vol 17 No. 1 - Maret 2020.

Bayu Dwi Anggono, “Omnibus Law Sebagai Teknik Pembentukan UndangUndang: Peluang Adopsi dan Tantangannya Dalam Sistem PerundangUndangan Indonesia", Jurnal Rechtsvinding Volume 9 Nomor 1, April 2020.

Cornelis Lay, "Democratic Transition in Local Indonesia-An Overview of Ten Years Democracy", Jurnal Ilmu Sosial dan Ilmu Politik Volume 15, Nomor 3, Maret 2012.

Dian Agung Wicaksono, \& Rahman, Faiz. "Penafsiran terhadap Kewenangan Mengatur Pemerintahan Daerah dalam Melaksanakan Urusan Pemerintahan melalui Pembentukan Peraturan Daerah" Jurnal Negara Hukum: Vol. 11, No. 2, November 2020.

Enny Nurbaningsih, "Berbagai Bentuk Pengawasan Kebijakan Daerah Dalam Era otonomi Luas", Jurnal Mimbar Hukum Volume 23, Nomor 1, Februari 2011. 
H.M. Laica Marzuki, “Menyoal Diskresi yang Terpasung (Mengkritisi Undang Undang Administrasi Pemerintahan)", Journal Amanna Gappa Vol. 25, No. 2 September 2017.

Herlambang P. Wiratraman, "Neo-Liberalisme, Good Governance dan Hak Asasi Manusia", Jurnal Hukum Jentera XV, Januari-Maret 2007.

Ibnu Sina Chandranegara, "Kompabilitas Penggunaan Metode Omnibus Dalam Pembentukan Undang-Undang", Jurnal Hukum Ius Quia Iustum No. 2 Vol. 27 Mei 2020.

Idul Rishan, "Risiko Koalisi Gemuk Dalam Sistem Presidensil", Jurnal Ius Quia Iustum, No. 2 Vol. 27 Mei, 2020.

Ima Mayasari, "Kebijakan Reformasi Regulasi Melalui Implementasi Omnibus Law", Jurnal Rechtsvinding Volume 9 Nomor 1, April 2020.

Larry Alexander, "Law and Politics: What is Their Relation", Harvard Journal of Law \& Public Policy, Volume 41 Issue 1, January 2018.

Louis Massicotte, "Omnibus Bills in Theory and Practice", Parliamentary Review Vol. 13, No. 1, 2013.

M. Adam Dodek, “Omnibus Bills: Constitutional Constraints and Legislative Deliberation", Ottawa Law Review Vol. 48 Issue 1,2017.

Mohamad Mova Al Afghani \& Bisariyadi, "Konsep Regulasi Berbasis Risiko: Telaah Kritis dalam Penerapannya pada Undang-Undang Cipta Kerja" Jurnal Konstitusi, Volume 18, Nomor 1, Maret 2021.

Ni'matul Huda, \& Heryansyah, Despan. "Kompleksitas Otonomi Daerah Dan Gagasan Negara Federal Dalam Negara Kesatuan Republik Indonesia", Jurnal Hukum Ius Quia Iustum, No. 2 Vol. 26 Mei 2019.

Ridwan, et all, "Perluasan Kompetensi Absolut Pengadilan Tata Usaha Negara dalam Undang-Undang Administrasi Pemerintahan" Jurnal Hukum Ius Quia Iustum, No. 2 Volume. 25 Mei 2018.

Siti Zuhro, “Otoda Dalam UU Pemda Baru: Pusat dan Daerah", Jurnal Penelitian Politik I Volume 13 No. 2 Desember 2016.

Wacipto Setiadi, "Simplifikasi Regulasi Dengan Menggunakan Metode Pendekatan Omnibus Law", Jurnal RechtsVinding, Vol. 9 No. 1, April 2020.

\section{Dokumen, Penelitian, Makalah \& Artikel}

A. Ahsin Thohari, "Menakar Omnibus Law", Opini Harian Koran Sindo, 30 Oktober 2019.

Antoni Putra, "Ironi Penyederhanaan Regulasi", Opini Koran Tempo, 17 Maret 2021.

Maria Farida Indrati, "Omnibus Law UU Sapu Jagat", Opini Harian Kompas, 4 Januari, 2020. 
Naskah Akademik, Rancangan Undang-Undang Cipta Kerja, Sekretariat DPR RI, Jakarta, 2019.

Organization for Economic Co-operation and Development, Reviews of Regulatory Reform, Government Capacity to Assure High Quality Regulation, OECD, September, 2012.

Patrick Keyzer, "The Indonesian Omnibus Law: Opportunities and Challenges", Makalah Materi Kuliah Umum, Universitas Brawijaya, Malang, 29 January 2020.

Pusat Studi Hukum dan Kebijakan Indonesia, Kajian Reformasi Regulasi di Indonesia: Pokok Permasalahan dan Strategi Penanganannya, PSHK: Jakarta 2019.

Sigit Riyanto, et al., Ringkasan Eksekutif Kertas Kebijakan Catatan Kritis Terhadap UU Nomor 11 Tahun 2020 Tentang Cipta Kerja, Fakultas Hukum Universitas Gadjah Mada, Yogyakarta, 2020. 